\title{
Peningkatan Kompetensi Sains melalui Model Pembelajaran Permainan Berpasangan
}

\author{
Slamet Mulyono \\ Kepala SDN Panggih Kec. Trowulan Kab. Mojokerto \\ Email: slametmulyono@yahoo.com
}

\section{Tersedia Online di \\ http://www.jurnal.unublitar.ac.id/ index.php/briliant}

\begin{tabular}{l}
\hline Sejarah Artikel \\
\hline Diterima pada 31 Maret 2017 \\
Disetuji pada 5 April 2017 \\
Dipublikasikan pada 1 Mei 2017 \\
Hal. 178-183 \\
\hline
\end{tabular}

Kata Kunci:

komptensi; sains, permainan berpasangan

\begin{abstract}
Abstrak. Tujuan Penelitian ini adalah untuk meningkatkan Prestasi Belajar Sains melalui model pembelajaran berpendapat dalam permainan berpasangan siswa kelas kelas IV SDN Panggih Mojokerto. Subjek penelitian ini adalah kelas IV SDN Panggih, Mojokerto. Dari hasil pengolahan dan analisis data siklus I dan II terdapat kenaikan sebagai berikut : Nilai rata-rata siklus I sebesar 65,33 mengalami kenaikan menjadi 70,87 pada siklus II. Ketuntasan belajar telah mencapai 27 siswa atau $90 \%$ padasiklus II dan pada siklus I yang tuntas 22 siswa atau $73,33 \%$, dengan demikian terjadi kenaikan ketuntasan belajar sebanyak 5 siswa atau sebesar $16,67 \%$.
\end{abstract}

Arah dan tujuan pembangunan bidang pendidikan telah tertuang dalam Undang-Undang Republik Indonesia Nomor 20 Tahun 2003 tentang sistem Pendidikan Nasional. Dalam pasal 3 UU RI ini telah ditetapkan fungsi dan tujuan pendidikan nasional yang berbunyi bahwa "pendidikan nasional berfungsi mengembangkan kemampuan dan membentuk watak serta peradaban bangsa yang bermartabat dalam rangka mencerdaskan kehidupan bangsa, bertujuan untuk berkembangnya potensi peserta didik agar menjadi manusia yang beriman dan bertakwa kepada Tuhan Yang Maha Esa, berakhlak mulia, sehat, berilmu, cakap,kreatif,mandiri dan menjadi warga negara yang berdemokratis serta bertanggung jawab" (2003:8).

Begitu pula khususnya pada mata pelajaran Sains merupakan salah satu pelajaran yang diberikan di sekolah dasar juga merupakan bagian yang tak terpisahkan untuk mmewujudkan tujuan pendidikan nasional tersebut. Sains merupakan suatu ilmu yang berlandaskan percobaan,dan pembelajaran sains tidak bersifat hafdalamn seperti mata pelajaran yang lainnya melainkan lebih menitik beratkan pada proses berpikir yang menurut siswa untuk ikut merasakan keterlibatan pendalamran dalam pembelajarannya melalui pengdalamman langsung dan observasi yang sungguh-sungguh relevan (Rustaman, 1997)

Hal ini seperti yang telah dituangkan dalam kurikulum bahwa melalui pembelajaran Sains di kelas IV sekolah dasar diharapkan siswa memiliki kompetensi dasar sebagai berikut: 1) Mendeskripsikan dalamt-dalat tubuh bagian dalam manusia dan hewan (organ pernafasan, pencernaan dan peredaran darah), 2) Memahami bahwa energi cahaya digunakan oleh tumbuhan untuk membuat makanan, 3) Mengaitkan ciri-ciri makhluk hidup dan lingkungan hidupnya, 4) Memanfaatkan saling keterkaitan antara ciri makhluk hidup dengan lingkungan 
teknologi dan masyarakat, 5) Mencari hubungan antara struktur sederhana penyusun suatu bahan dengan sifat-sifatnya, 6) Menyimpulkan bahwa benda dapat mengalami perubahan sifat (ada yang dapat kembali dan tidak ada yang dapat kembali ke wujud), 7) Menyelidiki pengaruh gaya terhadap bentuk dan gerak suatu benda.

Pembelajaran Sains tidak lain merupakan proses konstruksi pengetahuan melalui aktivitas berpikir siswa. Dalam kondisi seperti siswa diberi kesempatan untuk mengembangkan pengetahuannya secara mandiri melalui proses komunikasi yang menghubungkan pengetahuan awal yang dimiliki anak dengan pengetahuan yang akan mereka temukan dalam proses pembelajaran.

Proses pembelajaran Sains di kelas IV SDN Panggih, dalam kenyataannya masih belum memberikan hasil yang memuaskan sesuai dengan harapan KKM Sains yang telah ditetapkan oleh guru yaitu 60, di samping itu juga menunjukkan hanya 12 siswa yang mencapai ketuntasan belajar atau ketuntasan belajar klasikal baru mencapai 36,67\% dan nilai rata-ratanya baru berkisar 58,80 . Ternyata rendahnya prestasi belajar Sains yang diraih oleh siswa kelas IV SDN Panggih, disebabkan oleh beberapa faktor, antara lain: (a) Minimnya pemberian tugas untuk memecahkan suatu masalah Sains secara bersama, baik saat pembelajaran berlangsung maupun berakhir. (b) Kurang adanya praktikum sebagai wahana untuk berlatih siswa dalam upaya menyelesaikan tugas yang diberikan guru. (c) Minat siswa untuk membaca buku masih minim, terbukti dari hasil wawancara dengan siswa, rata-rata dari mereka membaca buku pelajaran hanya pada saat bila ada tugas atau jikahanya akan ada ulangan. (d) Siswa mengalami kejenuhan dan bosan pada waktu proses pembelajaran Sains berlangsung, karena guru hanya mengandalkan ceramah dalam penyampaian materinya, sehingga berdampak pada kurangnya perhatian, minat bahkan motivasi belajar siswa terhadap pelajaran Sains. Sehingga materi yang disampaikan kepada siswa pun masih bersifat abstrak, dan berakibat materi tersebut sulit untuk dihafalkan ataupun dipahami oleh siswa dan juga tidak bertahan lama dalam memori siswa. Proses pembelajaran hanya terpusat pada guru (teacher center) dan siswa hanya sebagai pendengar setia, tanpa melakukan aktivitas lainnya.

Oleh karena itu untuk memperbaiki dan meningkatkan prestasi belajar siswa diperlukan adanya peningkatan kualitas pembelajaran. Peningkatan kualitas pembelajaran ini dapat dilakukan melalui perubahan perubahan pemilihan strategi pembelajaran yang digunakan. Untuk mencapai hasil belajar yang optimal perlu keterlibatan atau partisipasi yang tinggi dari peserta didik dalam pembelajaran. Keterlibatan peserta didik merupakan hal yang sangat penting dan menentukan keberhasilan pembelajaran. Sujana dalam Mulyasa (2005:156) mengemukakan bahwa syarat kelas yang efektif adalah adanya keterlibatan, tanggung jawab dan umpan balik dari peserta didik. Keterlibatan peserta didik merupakan syarat pertama dalam kegiatan belajar di kelas. Untuk terjadinya keterlibatan itu peserta didik harus memahami dan memiliki tujuan yang ingin dicapai melalui kegiatan belajar.

Soedijarto $(1993 ; 25)$ menyatakan bahwa kualitas proses pembelajaran yang terjadi di dalam kelas dapat ditunjukkan oleh tingginya interaksi siswa dengan guru dan obyek belajar. Untuk itu guru harus berupaya agar siswanya dapat terlihat langsung secara aktif dalam setiap proses pembelajaran. Bruner dalam Abu Dori (1997:21) menyatakan bahwa "hasil belajar dengan cara belajar

179 BRILLIANT: Jurnal Riset dan Konseptual Volume 2 Nomor 2, Mei 2017 
mencari dan menemukan sendiri lebih mudah dihafalkan, diingat dan mudah ditransfer serta dapat menumbuhkan motivasi intrinsik/internal".

Salah satu model pembelajaran yang dapat mendorong dan membangkitkan serta meningkatkan peran serta aktif dari para siswa adalah model pembelajaran Permainan Berpasangan dalam Permainan Berpasangan yang dikemukakan oleh Silberman. Menurut Silberman (2005:115) menyatakan bahwa model pembelajaran Permainan Berpasangan dalam Permainan Berpasangan adalah model pembelajaran yang memberi kebebasan kepada siswa untuk saling Permainan Berpasangan dengan teman pasangannya yang ditandai dengan tanda pengenal. Selanjutnya dijelaskan pula bahwa kegiatan Permainan Berpasangan bisa digunakan untuk menstimulasi keterlibatan siswa dalam pelajaran yang akan anda sampaikan. Kegiatan ini juga mengingatkan siswa untuk mendengarkan secara cermat dan membuka diri terhadap bermacam pendapat.

Melalui model pembelajaran ini menurut Siberman (2005:115) siswa bebas bergerak mencari teman pasangannya untuk saling saling Berpendapat, sehingga siswa tidak hanya terpaku diam duduk di kursi, melainkan bergerak dengan bebas dan leluasa untuk mencari temannya, dan tercipta dalam pembelajaran yang dinamis dan kreatif serta menyenangkan bagi siswa, karena mereka dapat belajar sambil bermain mencari teman pasangannya.

Menurut Subagyo (1994:22) menyatakan bahwa model pembelajaran Permainan Berpasangan dalam Permainan Berpasangan adalah cara penyajian pelajaran di mana siswa secara berpasangan sesuai dengan tanda pengenal dihadapkan pada suatu masalah yang dapat berupa pernyataan yang bersifat problematik untuk dibahas dan dipecahkan bersama" Lebih lanjut dijelaskan oleh Hasibuan (1988:20), bahwa model pembelajaran Permainan Berpasangan dalam Permainan Berpasangan adalah salah satu cara penyajian bahan pelajaran di mana guru memberi kesempatan kepada para siswa (kelompok-kelompok kecil sesuai dengan pasangan tanda pengenal) untuk mengadakan perbincangan ilmiah guna mengumpulkan pendapat, membuat kesimpulan atau menyusun berbagai alternatif pemecahan atas suatu masalah"

Dari pendapat para ahli tersebut di atas dapatlah disimpulkan bahwa model pembelajaran Permainan Berpasangan dalam Permainan Berpasangan merupakan model pembelajaran yang memberi kebebasan kepada siswa untuk mencari teman pasangannya sesuai dengan tanda pengenal guna saling Permainan Berpasangan dengan pasangannya dalam upaya memecahkan problem yang diberikan guru.

Berdasarkan uraian sebelumnya maka untuk memperbaiki proses pembelajaran materi sain, peneliti model pembelajaran "Permainan Berpasangan dalam Permainan Berpasangan”. Menurut Melvin L Silberman (2005:116) bahwa langkah-langkah model pembelajaran ini adalah (1) Berikan label nama kepada tiap siswa. Perintahkan siswa untuk menuliskan nama mereka pada label dan mengenakannya. (2) Perintahkan siswa untuk berpasangan dan memperkenalkan diri pada siswa lain. Kemudian perintahkan pasangan-pasangan tersebut untuk berbagi pendapat tentang jawaban atas pertanyaan atau pernyataan provokatif yang memancing opini mereka tentang persodalamn seputar materi yang anda ajarkan (3) Ucapkan " kerjakan sekarang " dan arahkan siswa untuk bertukar label nama atau tanda pengenal mereka dengan pasangannya dan kemudian menemui siswa lain. (4) Selanjutnya perintahkan siswa untuk berganti

180 BRILLIANT: Jurnal Riset dan Konseptual Volume 2 Nomor 2, Mei 2017 
label nama lagi dan mencari siswa lain untuk diajak bicara dan berbagi pendapat dari siswa yang tanda pengenalnya ia kenakan sekarang (5)Lanjutkan proses itu hingga sebagian besar siswa telah saling bertemu. Kemudian katakan kepada tiap siswa untuk mendapatkan kembali label namanya sendiri.

\section{METODE}

\section{Rancangan Penelitian}

\section{Tahap Perencanaan}

Dalam hal ini langkah-langkah yang telah dipersiapkan antara lain: Menyusun RPP, dan butir-butir soal untuk evaluasi / ulangan harian, Mempersiapkan instrumen pengamatan dan instrumen tes, Menyiapkan daftar nilai

\section{Tahap Pelaksanaan}

Dalam tahap ini peneliti melakukan pengamatan/penelitian terhadap apa yang telah direncanakan dalam upaya meningkatkan prestasi belajar siswa pada mata pelajaran Sains.Partisipan melakukan pengamatan atas jalannya proses pembelajaran, dengan maksud agar mengetahui keaktifan dan keterlibatan siswa dan juga kompetensi guru dalam membimbing, mengarahkan dan memfasilitasi pembelajaran melalui penerapan model pembelajaran Permainan Berpasangan dalam Permainan Berpasangan.

Langkah Selanjutnya melakukan penilaian untuk mengukur sejauh mana siswa menguasaai dan memahami konsep tentang penyesuaian hidup dengan lingkungannya, setelah diberikan tindakan. Penilaian hasil belajar dilakukan dengan menggunakan tes tertulis bentuk pilihan ganda dan uaraian.

\section{Tahap Refleksi}

Setelah pengamatan selesai dilakukan dlaam rangka memperoleh data, maka data tersebut diolah untuk digunakan sebagai dasar menarik kesimpulan. Bila ternyata hasil kesimpulan tersebut menunjukkan hasil yang tidak sesuai dengan yang diharapkan maka perlu dicari faktor-faktor yang menyebabkan adanya ketidak tercapaian pelaksanaan penelitian tersebut.

\section{Waktu dan Tempat Penelitian}

Penelitian dilakukan sejak bulan Agustus 2016 sampai dengan bulan Oktober 2016 dan bertempat di SDN Panggih, Mojokerto.Tahun pelajaran 2016/2017

\section{Subjek Penelitian}

Subjek dalam penelitian ini adalah siswa kelas IV SDN Panggih, Mojokerto. Tahun Pelajaran 2016-2017 dengan jumlah 30 siswa terdiri dari 13 siswa laki-laki dan 16 siswa perempuan.

\section{Instrumen Penelitian}

Dalam penelitian ini instrumen meliputi lembar Tes, catatan lapangan tentang respn siswa, dokumentasi. 


\section{Teknik Analisis Data}

Analisis data dilakukan dengan menggunakan teknik analisis data deskriptif kualitatif baik yang bersifat linear (mengalir) maupun yang bersifat sirkuler. Rumus yang digunakan dalam mengolah dan menganalisis data antara lain: (1) Mencari rata-rata (Mean) $\bar{X}=\frac{\text { Jumlah nilai }}{\text { jumlah siswa }}$, (2) Mencari prosentase (\%) $\mathrm{P} \%=\frac{\text { Jumlah selisih nilai ygdiperoleh }}{\text { jumlah nilai yg diperoleh sebelumnyasiswa }}$, (3) Mencari ketuntasan belajar klasikal $K K M=\frac{\text { Jumlah yg tuntas }}{\text { jumlah siswa }}$.

\section{HASIL}

Dari hasil pengolahan dan analisis siklus I dan siklus II, secara keseluruhan ternyata ada perkembangan menuju kearah positif yaitu adanya kenaikan nilai rata-rata, nilai tertinggi, nilai terendah, ketuntasan belajar dan pencapaian peringkta prestasi belajar tinggi serta keterlibatan siswa dan juga respon siswa terhadap penerapan model pemeblajaran Permainan Berpasangan dalam permainan berpasangan tanda pengenal

Untuk lebih jelasnya peneliti paparkan perkembangan yang positif tersebut melaui table dan gradik sebagai berikut:

Tabel 1: Perkembangan prestasi belajar Sains prasiklus, siklus I sampai II

\begin{tabular}{|l|l|c|c|c|l|}
\hline \multirow{2}{*}{ No } & \multirow{2}{*}{ Unsur Perkembangan } & \multicolumn{3}{|c|}{ Siklus } & \multirow{2}{*}{ Kesimpulan } \\
\cline { 3 - 5 } & & Awal & I & II & \\
\hline 1 & Nilai rata-rata & 58,80 & 65,33 & 70,87 & Ada kenaikan \\
\hline 2 & Nilai tertinggi & 78 & 85 & 91 & Ada kenaikan \\
\hline 3 & Nilai terendah & 44 & 50 & 57 & Ada kenaikan \\
\hline 4 & Ketuntasan belajar & $30 \%$ & $73 \%$ & $90 \%$ & Ada kenaikan \\
\hline 5 & Peringkat prestasi & 0 & $67 \%$ & $67 \%$ & Ada kenaikan \\
\hline 6 & Tingkat keterlibatan & 0 & $79 \%$ & $93 \%$ & Ada kenaikan \\
\hline 7 & Tingkat respon siswa & 0 & $75 \%$ & $96 \%$ & Ada kenaikan \\
\hline
\end{tabular}

Apabila digambarkan melalui grafik sbb:

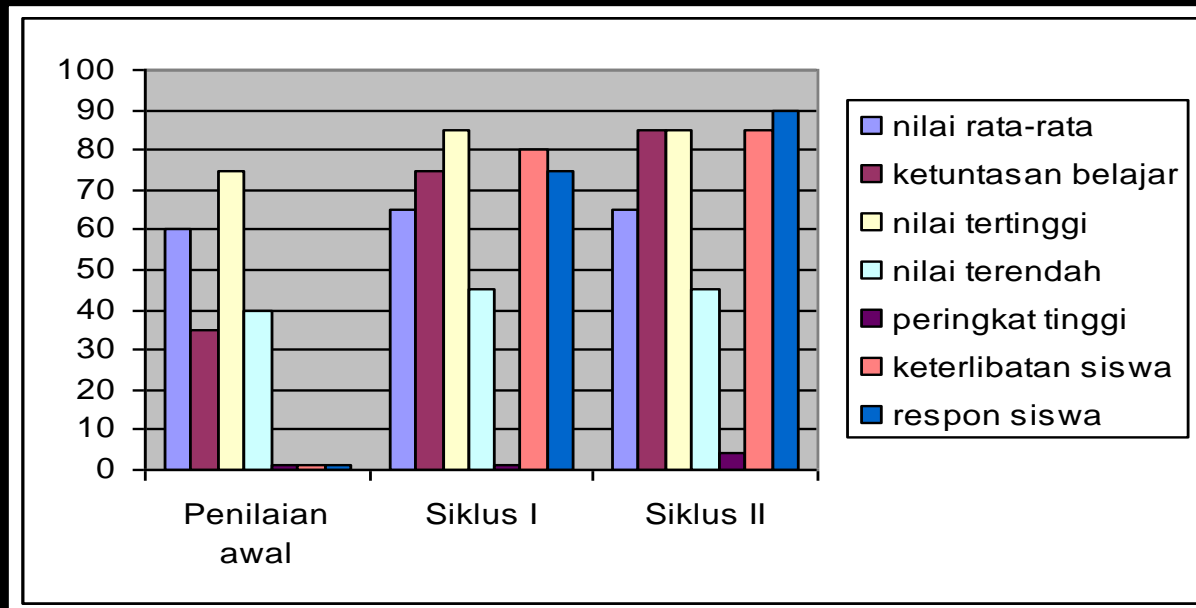




\section{PEMBAHASAN}

Jadi berdasarkan hasil analisis data tentang perkembangan prestasi belajar yang diraih para siswa maka dapatlah disimpulkan bahwa pembelajaran dengan menggunakan modelpembelajaran Permainan Berpasangan dalam Permainan Berpasangan ternyata prestasi belajar Sains pada siswa kelas IV SDN Panggih, Kecamatan Trowulan Mojokerto dapat meningkat secara optimal.

\section{KESIMPULAN}

Dari hasil analisis data pada siklus I dan II ternyata menunjukkan adanya perbaikan dan perkembangan nilai rerata, nilai tertinggi, nilai terendah dan perolehan peringkat prestasi belajar serta tingkat ketuntasan belajar siswa yang sangat signifikan sehingga dapatlah ditarik suatu kesimpulan bahwa dengan penggunaan model pembelajaran Permainan Berpasangan dalam proses pemebdalajaran ternyata prestasi belajar Sains siswa kelas IV SDN Panggih, Mojokerto dapat meningkat.

\section{SARAN}

Saran dalam penelitian ini adalah pelaksanaan guru harus selalu memberi reward/ penguatan atau pujian baik dalam bentuk fisik maupun non fisik kepada para siswanya. (2) Diharapkan pihak sekolah menyediakan sarana praktikum untuk memperlancar dan menunjang proses pembelajaran Sainns dan (3) Memperbanyak persediaan jumlah buku pelajaran Sains sesuai dengan jumlah siswa

\section{DAFTAR RUJUKAN}

Dahar, Ratna Wilis. 1988, Teori-teori Belajar. Bandung: P2LPTK

Dhori, Abu. 1997, Metodelogi Pembelajaran, PPPG IPS dan PMP, IKIP Mdalamng

Djamarah. Bakri. 1994. Prestasi Belajar Dan Kompetensi Guru. Surabaya: Usaha Nasional.

Muhajir, Noeng. 1993. Subjek didik, Jakarta: Rineka Cipta

Pasaribu, JJ., \& Moedjiono, 1995. Proses Belajar Mengajar, Bandung: CV. Remaja karya

Subagyo Rahman, 1984, Belajar PemBelajAran dan Metode-metode dalam Pemeblajaran, Jakarta: BRI Urusan Pendidikan dan Pelatihan.

Silberman, Melvin L. 2005, Active Learning 101: Cara Belajar Siswa Aktif, Bandung: Nusamedia.

Sriyono, dkk, 1991, Teknik Belajar Mengajar Dalam CBSA, Jakarta. RinekaKarya

Syah, Muhibbin. 2005. Psikologi Pendidikan Suatu Pendekatan Baru Bandung: Rsdakarya

Usman, M.U. 1995, Menjadi Guru Profesional. Bandung: Remaja Rosdakarya 